\title{
The SmartPlug and GeniusPlug: simple retrievable observatory systems for NanTroSEIZE borehole monitoring ${ }^{1}$
}

Achim Kopf, ${ }^{2,3}$ Demian M. Saffer, ${ }^{2}$ Earl E. Davis, ${ }^{4}$ Sebastian Hammerschmidt, ${ }^{2}$ Alison LaBonte, ${ }^{4}$ Robert Meldrum, ${ }^{4}$ Sean Toczko, ${ }^{2}$ Rachel Lauer, ${ }^{2}$ Martin Heesemann, ${ }^{4}$ Robert Macdonald, ${ }^{4}$

C. Geoffrey Wheat, ${ }^{2}$ Hans W. Jannasch, ${ }^{5}$ Katrina Edwards, ${ }^{6}$ Beth Orcutt, ${ }^{7}$ Amanda Haddad, ${ }^{6}$ Heinrich Villinger, ${ }^{8}$ Eiichiro Araki, ${ }^{2}$ Kazuya Kitada, ${ }^{2}$ Toshinori Kimura, $^{2}$ and Yukari Kido $^{2}$

\section{Chapter contents}

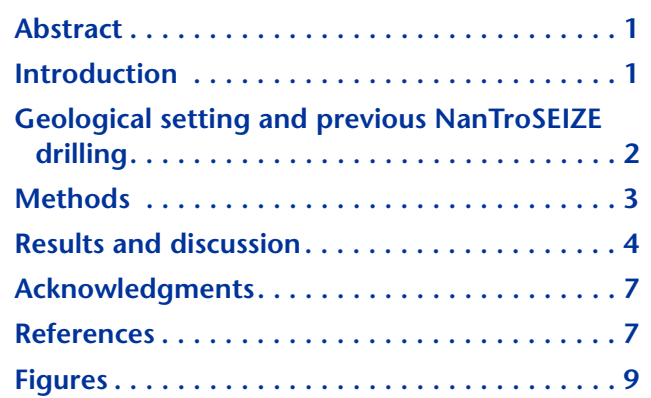

${ }^{1}$ Kopf, A., Saffer, D.M., Davis, E.E., Hammerschmidt, S., LaBonte, A., Meldrum, R., Toczko, S., Lauer, R., Heesemann, M., Macdonald, R., Wheat, C.G., Jannasch, H.W., Edwards, K., Orcutt, B., Haddad, A., Villinger, H., Araki, E., Kitada, K., Kimura, T., and Kido, Y., 2011. The SmartPlug and GeniusPlug: simple retrievable observatory systems for NanTroSEIZE borehole monitoring. In Kopf, A., Araki, E., Toczko, S., and the Expedition 332 Scientists, Proc. IODP, 332: Tokyo (Integrated Ocean Drilling Program Management International, Inc.).

doi:10.2204/iodp.proc.332.105.2011

2Expedition 332 Scientists' addresses.

${ }^{3}$ Correspondence author: akopf@marum.de

${ }^{4}$ Pacific Geoscience Centre, PO Box 6000, Sidney BC V8L 4B2, Canada.

${ }^{5}$ Monterey Bay Aquarium Research Institute, 7700 Sandholdt Road, Moss Landing CA 95039, USA.

${ }^{6}$ Department of Biological Sciences, Marine Environmental Biology Section, University of Southern California, Los Angeles CA 90089, USA.

${ }^{7}$ Center for Geomicrobiology, Arhus University, Ny Munkegade 116, 8000 Aarhus C., Denmark. ${ }^{8}$ Department of Geosciences, University of Bremen, Klagenfurter Strasse, 28359 Bremen, Germany.

\section{Abstract}

During Nankai Trough Seismogenic Zone Experiment (NanTroSEIZE) Stage 2 operations, Integrated Ocean Drilling Program (IODP) Hole C0010A was drilled and cased during IODP Expedition 319 and then subsequently instrumented with a temporary borehole monitoring system (a "SmartPlug"). The SmartPlug was recovered in November 2010 during IODP Expedition 332 and replaced with a "GeniusPlug." Both instruments were mounted beneath a Baker Hughes mechanically set retrievable casing packer. The casing packer was set just above the casing screen that intersects a major out-of-sequence splay fault, which branches off of the primary subduction thrust.

The SmartPlug was designed to document ambient conditions and provide proxies for strain and fluid flow related to tectonic and seismic activity within the splay fault. This was achieved by recording formation pressures and temperatures. Two pressure sensors were used (resolution $=10 \mathrm{ppb}$ full-scale, i.e., $\sim 0.7 \mathrm{~Pa}$, equivalent to $0.07 \mathrm{~mm}$ of seawater head), one plumbed to the formation via the casing screens below the packer seal and the other to the section of the borehole above the packer seal to record ocean loading signals. Temperature was recorded with a platinum thermometer and by a self-contained miniature temperature logger (MTL) with a resolution of $\sim 0.5 \mathrm{mK}$. The second-generation instrument package (i.e., GeniusPlug) consisted of a SmartPlug base unit to which an extension containing an OsmoSampler for fluid geochemistry and a FLOCS (flow-through osmo colonization system) unit for microbiology were added.

We report on the design of both instruments, the proof-of-concept after successful deployment of both instruments and recovery of the SmartPlug, and preliminary data from the SmartPlug that documents hydrologic responses to predominantly oceanographic loading and teleseismic earthquakes. Additional data and samples are anticipated in 2012 upon recovery of the GeniusPlug, at which time the GeniusPlug will be replaced by a permanent multisensor, multilevel borehole observatory system that will be connected to the seafloor fiber-optic cable network (Dense Oceanfloor Network System for Earthquakes and Tsunamis).

\section{Introduction}

The multiexpedition Integrated Ocean Drilling Program (IODP) Nankai Trough Seismogenic Zone Experiment (NanTroSEIZE) will 
complete a transect of holes drilled through the Nankai accretionary prism, with coring, logging, and long-term monitoring experiments examining faults and wall rock at various depths, ultimately including the seismogenic part of the subduction thrust fault (Fig. F1A). As part of operations at IODP Site C0010, a mechanically set retrievable packer (Baker Hughes A3 Lok-Set) equipped with a small instrument package to monitor pore pressure and temperature was installed inside a $105 \%$ inch casing string during IODP Expedition 319 (see Saffer et al., 2009). This instrument package, termed a "SmartPlug," was deployed for $1 \mathrm{y}$ at 374 meters below seafloor (mbsf), immediately above a screened casing interval within the shallow megasplay fault zone (Fig. F1B) (Saffer, McNeill, Byrne, Araki, Toczko, Eguchi, Takahashi, and the Expedition 319 Scientists, 2010). The instrument package included a data logger, a temperature sensor within the data logger housing, a self-contained temperature sensor, and two pressure gauges. These pressure sensors monitored (1) below the packer seal in a screened interval that is open to the fault zone and (2) above the packer seal to serve as a hydrostatic reference open to the overlying water column. Both temperature sensors were just below the packer (Fig. F2A). The SmartPlug instruments developed in 2009 monitored formation pore pressure and temperature from the time the bridge plug was set (23 August 2009) until they were retrieved during IODP Expedition 332 (7 November 2010). In 2010, an upgraded version of the plug, termed "GeniusPlug," was developed. It relies on the SmartPlug design but replaces its end cap (the bullnose) with a second unit of the same diameter and adds $30 \mathrm{~cm}$ length (Fig. F2B). It hosts a continuous fluid sampler (OsmoSampler; Jannasch et al., 2004) and a microbiological colonization experiment (flow-through osmo colonization system [FLOCS]; Orcutt et al., 2010).

\section{Geological setting and previous NanTroSEIZE drilling}

The Nankai accretionary complex off the coast of southwest Japan is formed by subduction of the Philippine Sea plate beneath the Eurasian plate along the Nankai Trough (Kinoshita et al., 2007). The southwestnortheast striking accretionary wedge mainly consists of off-scraped and underplated materials from the trench-fill turbidites and the incoming Shikoku Basin hemipelagic sediments (Moore et al., 2009). Much of what is known about the Nankai Trough subduction zone results from earlier scientific drilling in the Deep Sea Drilling Project and Ocean Drilling Program as well as an extensive 3-D seismic reflection survey (Moore et al., 2007, 2009). Drilling and geophysical surveys along two transects in the western (off Ashizuri Peninsula) and central part (Muroto Peninsula) of the study area shed light on the regional geology of both the incoming and accreted sediment (e.g., Taira, Hill, Firth, et al., 1991; Moore et al., 2001; Ike et al., 2008). A third transect offshore of the Kii Peninsula, now termed the NanTroSEIZE transect, was the target of subsequent 3-D seismic reflection work (Moore et al., 2007, 2009; Bangs et al., 2009; Strasser et al., 2009). Apart from the master décollement, a prominent splay fault system was imaged that is invoked as a candidate for coseismic slip (e.g., Moore et al., 2007).

From 2007 until the present, a series of expeditions took place under the umbrella of the IODP complex drilling project NanTroSEIZE (for an outline of the objectives, see Tobin and Kinoshita, 2006). One of the key scientific goals is to shed light on the nature of the different fault zone materials within the Nankai Trough accretionary complex and how their physical properties vary as a function of depth and distance from the deformation front (i.e., with increasing pressure and temperature [P-T]). Several hypotheses are to be tested with respect to the downdip transition from aseismic deformation at shallow depth to stick-slip behavior and earthquake rupture at depths greater than $\sim 5-6 \mathrm{~km}$ (e.g., Tobin and Kinoshita, 2006). This approach requires a transect of holes spanning from the undeformed sediment of the incoming Philippine Sea plate across the frontal to the central portion of the accretionary wedge (Fig. F1A). During three stages of drilling, drill sites have sampled the downgoing plate (IODP Sites C0011 and C0012), the frontal wedge (IODP Sites C0006 and C0007), sediments draping the midslope (IODP Site C0008), the shallow splay fault (IODP Sites C0001, C0003, C0004, and C0010) and the Kumano forearc basin (IODP Sites C0002 and C0009) (Tobin et al., 2009; Screaton et al., 2009; Ashi et al., 2009; Saito, Underwood, Kubo, and the Expedition 322 Scientists, 2010; Saffer, McNeill, Byrne, Araki, Toczko, Eguchi, Takahashi, and the Expedition 319 Scientists, 2010). A second key objective of the NanTroSEIZE project is to develop and install a distributed network of borehole observatories spanning the upper transition from aseismic to seismic slip in order to provide long-term and continuous records of subsurface fluid pressure, temperature, strain, tilt, and seismicity (e.g., Tobin et al., 2009).

The borehole observatory systems installed to date have focused on the shallow portion of the megasplay fault and the seaward edge of the Kumano Basin (Expedition 319 Scientists, 2010). Here, we describe the temporary instrument installations at Site C0010 (SmartPlug and GeniusPlug); a companion 
manuscript by E. Araki et al. (unpubl. data) describes the permanent observatory system and its installation at Site C0002. The megasplay fault was penetrated at two sites along the NanTroSEIZE transect: (1) Stage 1 drilling at Site C0004 (Tobin et al., 2009), which collected logging-while-drilling (LWD) data during IODP Expedition 314 and continuously cored the section during IODP Expedition 316, and (2) Stage 2 drilling, casing, and SmartPlug installation at Site C0010, located $\sim 3.5 \mathrm{~km}$ along strike of Site C0004 to the southwest, during Expedition 319 (Saffer, McNeill, Byrne, Araki, Toczko, Eguchi, Takahashi, and the Expedition 319 Scientists, 2010). At both sites, a similar sequence was drilled (Fig. F1B).

Combined analysis of 3-D seismic and age constraints from drilling indicate that the tectonostratigraphic system in this area evolved $\sim 2.2 \mathrm{~m}$.y. ago in a frontal prism toe position when an emerging trenchslope basin was formed in concert with in-sequence forward imbrication of accreted strata (Strasser et al., 2009). Splay fault movement initiated $\sim 1.95$ m.y. ago as an out-of-sequence thrust (OOST) in the lower part of the prism. Since $\sim 1.55 \mathrm{Ma}$, this initial OOST was uplifted and became reactivated, favoring ongoing "megasplay" slip along it (Strasser et al., 2009). Along the NanTroSEIZE drilling transect, it appears that displacement along the shallow segment of the megasplay fault ceased at $\sim 1.24 \mathrm{Ma}$, suggesting that it only experienced a relatively short period of high activity between $\sim 1.55$ and 1.24 Ma (Strasser et al., 2009). Seismic data clearly show that the megasplay truncates very young sediments near the seabed west of the study area (Moore et al., 2007), suggesting that segments of the fault system are currently or recently active. However, variations in fault activity and architecture along strike indicate that in some areas, the megasplay fault system includes several branches and that fault activity may be distributed along these branches as well as expressed by distributed deformation of the overlying slope sediments (e.g., Moore et al., 2009; Kimura et al., 2011). Thus, splay fault activity and deformation in the surrounding geologic bodies are interrelated. The wealth of information in the area adjacent to Sites $\mathrm{C0004}$ and $\mathrm{C0010}$ indicates that monitoring strain as a function of modern splay fault activity represents a promising target for NanTroSEIZE observatories.

The geology at Site C0010 includes a $200 \mathrm{~m}$ thick sequence of slope apron deposits composed of silty mudstone with some thin sand and ash layers overlying a $\sim 210 \mathrm{~m}$ thick wedge of fractured mudstone comprising a thrust sheet in the hanging wall of the megasplay fault (e.g., Moore et al., 2009; Saffer, McNeill, Byrne, Araki, Toczko, Eguchi, Takahashi, and the Expedition 319 Scientists, 2010). The fault juxtaposes the thrust wedge above with overridden slope apron sediments below, which consist of silty mudstone with numerous sand beds and some ash (Kimura et al., 2008; Moore et al., 2009). The character of the megasplay fault zone in seismic reflection images differs markedly between Sites C0004 and C0010 (e.g., Flemings et al., 2009). At Site C0004, there are two distinct reflectors at the base of the thrust wedge; both coring and LWD data document the presence of two main fault zones separated by a $\sim 50 \mathrm{~m}$ thick "fault-bounded package" (e.g., Kimura et al., 2008). In contrast, at Site C0010, the megasplay is imaged as a single sharp reflector in the seismic data, suggesting that it would be thinner and perhaps have a simpler architecture than the fault at Site C0004. During Expedition 319, a bottom-hole assembly was made up of a $12^{1 / 4}$ inch bit with an $8 \frac{1}{4}$ inch LWD geoVISION tool measuring natural gamma ray and resistivity and the measurement while drilling (MWD) PowerPulse measuring direction and inclination, torque, and weight on bit. After MWD and LWD drilling to $402 \mathrm{mbsf}, 20$ inch casing was run into the hole. Two joints of screened casing (22 m length) were placed at 387-409 mbsf to span the fault zone at $407 \mathrm{mbsf}$ as interpreted from LWD and seismic reflection data (Saffer, McNeill, Byrne, Araki, Toczko, Eguchi, Takahashi, and the Expedition 319 Scientists, 2010). This configuration is outlined schematically in Figure F1B.

\section{Methods}

The general design of the SmartPlug deployed during Expedition 319 remained little changed for Expedition 332 given the robust design and ease of handling. Structurally, both "plugs" included a hollow-bore 3.5 inch EU 8rd box-end threaded coupling at the upper end, which mates with the lower end of the Baker Hughes packer, and an outer O-ring sealed structural shell that is designed to withstand the loads encountered during hole reentry operations (Figs. F2A, F3) (see also "SmartPlug/GeniusPlug" in the "Methods" chapter [Expedition 332 Scientists, 2011]). Housed inside are a high-precision pressure period counter with a $12.8 \mathrm{MHz}$ real-time clock (RTC-PPC system, resolving $\sim 10 \mathrm{ppb}$ of full-scale pressure, or $\sim 0.7 \mathrm{~Pa}$ ), a 24-bit/channel analog to digital converter and data logger (designed and built by Bennest Enterprises, Ltd., Minerva Technologies, Ltd., and the Pacific Geoscience Centre, Geological Survey of Canada), two pressure sensors (Model 8B7000-2-I; Paroscientific, Inc., USA), and an independent miniature temperature logger (MTL) (Antares, Germany). Four independent temperature readings are made: (1) with the MTL, (2) with a platinum thermometer mounted on the primary data logger end cap, and (3) with each of the two pressure sensors. The inside of the structural shell is 
exposed to water in the cased borehole above through the internal open bore of the casing packer seal. One of the pressure sensors is connected to this volume to provide a hydrostatic reference, and the second sensor is connected to the sealed, screened borehole interval via hydraulic tubing that passes through the bottom end of the structural shell. RS422 communications with the main instrument for setting recording parameters and downloading data are conducted via a multisegment Seacon AWQ connector on the logger pressure case. Communications with the MTL are conducted with a special Antares interface and WinTemp software. The instrument frame is shock-mounted within the structural shell, and the pressure sensors are mounted with secondary shock pads within the frame (Fig. F2B). Structural components are constructed with 4140 alloy steel, and pressure sensor housings and hydraulic tubing are constructed from 316 stainless steel.

The extension unit for the GeniusPlug configuration is made of the same material and includes a bulkhead to hydraulically separate the SmartPlug body from the OsmoSampler and FLOCS (Figs. F2B, F4, F5). The OsmoSamplers will provide a time series of pore fluid geochemical data from the screened interval in order to asses any fluid flow or geochemical transients (e.g., Solomon et al., 2009). The FLOCS experiment is designed for in situ cultivation of microbial populations and to evaluate turnover rates and carry out DNA sequencing on populations of microbes on the different substrates included in the chambers. Because these observatory components were added to the bottom end of the SmartPlug configuration, only borehole fluid entering through the casing screens enters the lower portion of the instrument where the intakes for the OsmoSampler and FLOCS are located. These two experiments are constrained in a 7.15 inch high and 6.3 inch diameter space. The OsmoSampler has two 2ML1 ALZET membranes attached to the housing with two-part epoxy (Hysol ES1902). The ends of the distilled water and saturated salt (noniodized table salt, $\mathrm{NaCl}$ ) reservoirs are sealed with a single O-ring and held in place with a setscrew. This configuration will pump $73 \mathrm{~mL} / \mathrm{y}$ at $20^{\circ} \mathrm{C}$. The pump is attached to $150 \mathrm{~m}$ of small-bore Teflon tubing that holds $170 \mathrm{~mL}(1.19 \mathrm{~mm}$ inside diameter and $2.0 \mathrm{~mm}$ outside diameter). The tubing was filled with $10 \% \mathrm{HCl}$ for 5 days before it was rinsed with $18.2 \mathrm{M} \Omega$ water. Thus, this sampler can be deployed at $20^{\circ} \mathrm{C}$ for $2 \mathrm{y}$ and maintain a continuous record for longer if the borehole temperature is cooler than $20^{\circ} \mathrm{C}$.

The FLOCS experiment is attached to two pumps, each identical to the ones described above for the OsmoSampler (Figs. F2B, F4). Both pumps are attached via a T-connection to double the pump rate $\left(146 \mathrm{~mL} / \mathrm{y}\right.$ at $\left.20^{\circ} \mathrm{C}\right)$. These pumps are attached to $150 \mathrm{~m}$ of small-bore Teflon tubing that holds $170 \mathrm{~mL}$ and were prepared as above. At $20^{\circ} \mathrm{C}$ these pumps will fill the sample coil in $\sim 14$ months. The pumps will continue to work because of the amount of excess salt in the pump but will only preserve the last 14 months of fluid within the sample coil. The loss of the early portion of the record was deemed acceptable because the FLOCS is filled with about $50 \mathrm{~mL}$ of sterile seawater that must pass through the coils before borehole fluids are collected within the coils. As this sterile seawater enters the distilled water portion of the pump, it will decrease the pump rate but only minimally, even for a 2 y deployment. The inlet was attached to a syringe with $18.2 \mathrm{M} \Omega$ water until just before deployment.

The FLOCS experiment consists of a single unit that has four chambers. All of the parts were sterilized and materials packed with sterile tools in a hood. The chamber closest to the inlet contained two grids with autoclaved rock chips (1-2 $\mathrm{mm}$ thick and $5 \mathrm{~mm}$ $\times 5 \mathrm{~mm}$ ) mounted on them facing out. These two grids were separated by autoclaved glass wool and $5 \mathrm{~mm}$ borosilicate glass beads. Rock chips were attached to the plastic grids using "5 min epoxy." One grid has basalt glass in the bottom portion (AT11-204055-B6) and basalt above it (J2-246-R2). The other grid has basalt in the bottom portion (J2-244-R4) and olivine above it. Above the grids are three chambers filled with barite, olivine, and NanTroSEIZE Expedition 316 sediment, respectively. The latter was a clayey mud recovered at Site C0004, comprising material from a depth equivalent to the depth interval near the megasplay fault zone in Hole C0010A some $3 \mathrm{~km}$ away from Site C0004 (see Tobin et al., 2009; Saffer, McNeill, Byrne, Araki, Toczko, Eguchi, Takahashi, and the Expedition 319 Scientists, 2010). These materials were crushed from bulk rocks, sieved to $<250 \mu \mathrm{m}$, and autoclaved. Teflon mesh screens were placed inside the cassette caps to prevent rock fragments from escaping the cassette. At sea, the FLOCS was filled with $\sim 50 \mathrm{~mL}$ of sterile seawater. Additional seawater was added to remove air bubbles. During this process, some of the sediment from the end capsule escaped. The inlet was attached to a syringe with sterile seawater until just before deployment.

\section{Results and discussion}

\section{Operations}

The two SmartPlug instruments built in 2009 were set to begin recording data at the time they were shipped from the Pacific Geoscience Centre, Canada, to Shingu Port, Japan, on 11 April 2009, and stored in Shingu until they were transported to the $\mathrm{D} / \mathrm{V}$ 
Chikyu via supply boat for Expedition 319 . Because one of them (Instrument 82) was not deployed during the cruise, it was shipped back to Shingu and stored in a warehouse until 2010. It was loaded onto the Chikyu during the preexpedition port call on 26 October 2010 and hence contained an 18 month record of data by the time Expedition 332 began. Logging intervals for the formation and hydrostatic pressure sensors ( $\mathrm{P}_{\text {form }}$ and $\left.\mathrm{P}_{\text {hyd }}\right)$ and the internal platinum thermometer were set to $1 \mathrm{~min}$; at this rate and with other operational parameters as set, battery power (provided by six Tadiran TL-5137 DD primary lithium cells) is the limiting factor for operational lifetime, which is roughly $7 \mathrm{y}$, including a de-rating factor of $75 \%$ applied to full power withdrawal. The instruments are equipped with $512 \mathrm{MB}$ (low power) flash memory cards, which provide a (theoretical) storage capacity until the year 2038 at a 1 min sampling rate. The independent MTL in Instrument 82 was set to sample temperature at 60 min intervals. The main logger clock was synchronized to Universal Time Coordinated (UTC) on 11 April 2009, and the MTL clocks were set on approximately the same date. The clock was synchronized to UTC again on 6 November 2010 prior to deployment.

A third SmartPlug was fabricated in 2010 and followed an identical design. This instrument package was set to a sampling interval of $30 \mathrm{~s}$, resulting in a (theoretical) storage capacity until the year 2033. Also, the software developed for programming and communication with the instrument was updated for the 2010 instruments. The third instrument was prepared so that it could be used as a backup in case time limitations on operations in Hole C0002J would not allow deployment of the planned longterm borehole monitoring system (LTBMS) (see "Long-term borehole monitoring system" in the "Methods" chapter [Expedition 332 Scientists, 2011]). All configurations and potential damage during shipping were checked prior to deployment onboard the Chikyu (Fig. F3).

The two GeniusPlug extension units were assembled during the first weeks of Expedition 332. As described above, the OsmoSamplers were designed for a deployment duration of up to 24 months. The FLOCS chambers were filled with various types of rock chips, including clayey silt recovered adjacent to the splay fault at Site C0004 (see Tobin et al., 2009, for details). All chambers and tubing were carefully saturated with sterile seawater so that no air got trapped inside before all components were placed in the extension unit at the bottom of the plug. As a final step, the tubing from the downwardlooking pressure transducer was connected at the bullnose end cap using a Swagelok fitting (Fig. F5C).
The first SmartPlug was directly attached to the bridge plug and was installed successfully during Expedition 319 on 23 August 2009 (Figs. F5A, F6A) (Expedition 319 Scientists, 2010). It was recovered on 7 November 2010 during Expedition 332 (Kopf et al., 2010). The GeniusPlug was mounted to a second bridge plug and deployed on 11 November 2010.

\section{Results}

Complete records are shown for the downwardlooking (megasplay fault zone $\left[\mathrm{P}_{\text {form }}\right]$; Fig. F7A) and upward-looking (hydrostatic reference $\left[\mathrm{P}_{\text {hyd }}\right]$; Fig. F7B) pressure response and the pressure anomaly (i.e., excess pore pressure; Fig. F7C). The full records clearly show an increase in formation pressure and a subtle decrease in the seafloor reference but an overall increase in excess pore pressure.

The $\mathrm{P}$ records can be separated into six intervals. Period I, lasting until Day 61, shows $P_{\text {hyd }}$ increasing at a rate of $1500 \mathrm{kPa} /$ day, whereas $P_{\text {form }}$ is falling at a similar rate. Period II (Days 61-154) is characterized by reference and borehole pressures that show a steady decline of $300 \mathrm{kPa} /$ day and a steady increase of $360 \mathrm{kPa} /$ day, resulting in excess pore pressure rises of $0.07 \mathrm{kPa} /$ day. During Period III (Days 154-215), the rate of $\mathrm{P}$ decay (seafloor) and rise (formation) decreased to $35 \mathrm{kPa} /$ day and $145 \mathrm{kPa}$ /day, respectively. Period IV (Days 215-300) shows higher rates once again $\left(\mathrm{P}_{\text {hyd }}=-179 \mathrm{kPa} /\right.$ day, $\mathrm{P}_{\text {form }}=291 \mathrm{kPa} /$ day $)$, resulting in the excess pore pressure rising at $0.05 \mathrm{kPa} /$ day (Fig. F7C). The following Period V (Days 300-352) is characterized by rates of $22 \mathrm{kPa} /$ day for $\mathrm{P}_{\text {hyd }}$ and $110 \mathrm{kPa}$ /day for $\mathrm{P}_{\text {form }}$. In contrast to other periods, pressure records show no opposite behavior but a simultaneous increase. Period VI (Days 352-452) shows a decreasing rate in $\mathrm{P}_{\text {hyd }}(269 \mathrm{kPa} /$ day $)$ and a rise to $430 \mathrm{kPa} /$ day for $\mathrm{P}_{\text {form }}$. Hence, the excess pore pressure shows an increase of $0.07 \mathrm{kPa}$ /day (Fig. F7C). The records suggest that the borehole had not fully equilibrated by the time the instrument was recovered some 15 months after deployment. The data also demonstrate that the bridge plug effectively sealed the borehole because upon reentry of the drill string and latching onto the device during Expedition 332, the upward-looking pressure sensor shows a strong fluctuation owing to displacement of borehole fluid, whereas the downward-looking pressure sensor encounters no such interference and remains at a near-constant value (Fig. F8). Hydraulic isolation of the monitoring interval is also documented by (1) the observation that the ambient pressures are different by $\sim 10 \mathrm{kPa}$ for the two transducers and (2) the attenuation of the ocean tidal loading signal in the $\mathrm{P}_{\text {form }}$ record. 
Regardless of the overall trend, three different types of transient pressure excursions were observed:

1. Pressure pulses of up to several $100 \mathrm{~Pa}$ in sudden amplitude change that lasted for 20-60 min, which are largely associated with teleseismic events;

2. Tremorlike signals of a fraction of a kilopascal with durations of hours or even days, which can be associated with atmospheric and oceanographic events such as low-pressure systems, storm waves, and tsunamis; and

3. Smaller individual pulses of low amplitude $(<1 \mathrm{kPa})$ that lasted for only minutes, which are tentatively associated with either low-magnitude deformational events in the accretionary complex or the overlying seafloor.

In this short note, we only give one example for each of the phenomena mentioned above. However, postcruise research is ongoing and a detailed study will be published in the near future (e.g., S. Hammerschmidt et al., unpubl. data). Figure F9 shows the pore pressure anomaly associated with the Maule M 8.8 earthquake in Chile, which occurred on 27 February 2010 and was one of the most prominent subduction thrust ruptures in recent times (Moreno et al., 2010). Pressure waves produced $200 \mathrm{~Pa}$ in excess of $\mathrm{P}_{\text {hyd }}$ in the formation and arrived almost $24 \mathrm{~h}$ earlier than the tremorlike signal of the associated tsunami wave. The latter showed stronger $\mathrm{P}_{\text {hyd }}$ amplitudes compared to $\mathrm{P}_{\text {form }}$, but maxima ranged only 60-75 Pa (see Fig. F9C). It can be seen that the incoming tsunami waves have periods of up to $10 \mathrm{~min}$ and that the signals span a period $>12 \mathrm{~h}$.

A second type of tremorlike signal, equally spanning over many hours or even days, is attributed to the transient pressure changes associated with lowpressure weather systems and storm waves and higher swell. Among the many examples that can be found during the period of SmartPlug monitoring, Typhoon Chaba is shown in Figure F10A. This low-pressure front hit the coast of Japan at the time the Chikyu was bound for Expedition 332 at Shingu Port, and in fact caused an early departure and a period of waiting on weather during late October 2010. The record attests that both $P_{\text {hyd }}$ and $P_{\text {form }}$ are loaded in a similar manner and magnitude.

The third type of short-period tremor, or sometimes just a series of individual pulses, is believed to result from internal deformation within the Nankai Trough accretionary complex. Those events of microseismic activity at very low frequencies were first described for the NanTroSEIZE area by Obara and Ito (2005) and attest that interseismic strain is not confined to slow elastic strain accumulation. Figure F10B shows a sudden $\sim 350 \mathrm{~Pa}$ increase as a function of such a very low frequency event. Similar events were identified in various parts of the $450+$ day record; however, two factors hamper their clear interpretation: (1) the relatively long sampling interval of $60 \mathrm{~s}$, which may result in shorter deformation events being missed; and (2) the wealth of Japanese earthquake monitoring stations that have yet to analyze all of the data.

The temperature data are less meaningful than the $P$ transients. Figure F11 provides an example of the full $\mathrm{T}$ data set comprising the two Paroscientific transducers, the platinum chip inside the pressure housing, and the self-contained ANTARES MTL, which show minor shifts but otherwise plot along the same narrow corridor. The data set attests that $\mathrm{T}$ is still recovering from the sudden drop during deployment, so a period $>15$ months is required to reach ambient background $\mathrm{T}$ values.

One peculiarity in the otherwise fairly homogeneous records from the four thermistors is an event around the 295th day into the monitoring phase. This sudden change in T lasted $\sim 1.5$ days and shows an increase in the MTL temperature as well as the T sensors in the two pressure transducers, whereas the sensor in the pressure housing experienced a drop in temperature. So far, no correlation with either the SmartPlug pressure data or with the United Stated Geological Survey or local Japanese earthquake (EQ) catalogs could be made.

\section{Preliminary interpretation of the data set}

Although detailed analysis of the full data set is ongoing, there are several key preliminary conclusions from the initial deployment and data review:

1. The Baker Hughes bridge plug effectively sealed the cased Hole C0010A as demonstrated by the significantly different response of the upwardand downward-looking pressure transducers when the drill string reentered Hole C0010A during SmartPlug recovery (see Fig. F8), the attenuated response of the formation pore pressure to tidal loading, and the $\sim 10 \mathrm{kPa}$ difference in ambient pressure recorded by the upward-looking and downward-looking pressure sensors.

2. It appears that the plug settled $\sim 50 \mathrm{~cm}$ over the first 2 months of deployment or some of the thread grease or anticorrosion additive to the borehole fluid was mucking the inside of the instrument (and hence the upward-looking pressure transducer) and apparently loaded the seafloor sensor, resulting in a gradual increase in measured reference pressure of $\sim 1500 \mathrm{kPa}$ /day over this time interval (see Period I, Fig. F7).

3. The formation is slightly overpressured $(\sim 10 \mathrm{kPa})$ and appears to be still recovering at the end of the record (Fig. F7). The temperature record over 
the entire monitoring period supports this conclusion, with T still rising at the end of the record when the SmartPlug was recovered (Fig. F11).

4. The temperature records are well resolved but show yet-to-be-explained offsets, which may have something to do with a change in the thermal insulation around the sensors or the instrument pressure case, the changing nature of heat dissipation, or hydrogeologic events such as earthquake loading of the formation. Postcruise research may shed light on the observed problem of opposite temperature trends from different sensors during the same event (Fig. F11, inset).

5. Even with low-frequency sampling (60 s interval) the pressure records document responses to several earthquake events and associated Rayleigh and tsunami waves. The tsunami waveform related to the Maule, Chile, M 8.8 earthquake (see Fig. F9) is similar to existing records from, for example, the NEPTUNE seafloor cabled network (E. Davis, pers. comm., 2010) but has larger amplitude and a more persistent pressure signal lasting 3-4 days. Further, it demonstrates the more effective, frequency-dependent loading of the formation (seen in pressure fluctuations) from Rayleigh waves compared with tsunami loading.

6. The loading efficiency at the tsunami frequency is virtually identical to that of 0.82 at tidal frequency, illustrating the undrained, instantaneous response to overburden hydrostatic stress transients.

7. Subtle changes in pressure may be related to strain events within the Nankai accretionary prism, the most prominent of which occurred on 28 September 2009 (see Fig. F10B) and 5 January 2010. However, local EQ catalogs will need to be consulted in a future detailed study in order to confidently correlate pressure transients with tectonic strain events.

\section{Acknowledgments}

Samples and/or data were provided by the Integrated Ocean Drilling Program (IODP). We acknowledge funding by the German Science Foundation (to Kopf through DFG grant KO2108/8-1), the US National Science Foundation (to Saffer), and the Moore Foundation (to Edwards).

\section{References}

Amante, C., and Eakins, B.W., 2008. ETOPO1 1 Arc-Minute Global Relief Model: Procedures, Data Sources and Analysis: Washington, DC (DOC/NOAA/NESDIS/NGDC).

Ashi, J., Lallemant, S., Masago, H., and the Expedition 315 Scientists, 2009. Expedition 315 summary. In Kinoshita,
M., Tobin, H., Ashi, J., Kimura, G., Lallemant, S., Screaton, E.J., Curewitz, D., Masago, H., Moe, K.T., and the Expedition 314/315/316 Scientists, Proc. IODP, 314/315/ 316: Washington, DC (Integrated Ocean Drilling Program Management International, Inc.). doi:10.2204/ iodp.proc.314315316.121.2009

Bangs, N.L.B., Moore, G.F., Gulick, S.P.S., Pangborn, E.M., Tobin, H.J., Kuramoto, S., and Taira, A., 2009. Broad, weak regions of the Nankai megathrust and implications for shallow coseismic slip. Earth Planet. Sci. Lett., 284(1-2):44-49. doi:10.1016/j.epsl.2009.04.026

Expedition 319 Scientists, 2010. Site C0010. In Saffer, D., McNeill, L., Byrne, T., Araki, E., Toczko, S., Eguchi, N., Takahashi, K., and the Expedition 319 Scientists, Proc. IODP, 319: Tokyo (Integrated Ocean Drilling Program Management International, Inc.). doi:10.2204/ iodp.proc.319.104.2010

Expedition 332 Scientists, 2011. Methods. In Kopf, A., Araki, E., Toczko, S., and the Expedition 332 Scientists, Proc. IODP, 332: Tokyo (Integrated Ocean Drilling Program Management International, Inc.). doi:10.2204/ iodp.proc.332.102.2011

Flemings, P.B., Kano, Y., Conin, M., Saffer, D.M., Buchs, D.M., Cukur, D., Huftile, G., Kawabata, K., Moore, C., Moe, K., Toczko, S., Araki, E., McNeill, L.C., Byrne, T.B., Moore, G.F., the Expedition 319 Science Party, and Darnell, K., 2009. Architecture and along-strike variation of the Nankai megasplay fault: results from IODP Expedition 319. Eos, Trans. Am. Geophys. Union, 90(52)(Suppl.):T12A-03. (Abstract) http:// www.agu.org/meetings/fm09/waisfm09.html

Ike, T., Moore, G.F., Kuramoto, S., Park, J.-O., Kaneda, Y., and Taira, A., 2008. Variations in sediment thickness and type along the northern Philippine Sea plate at the Nankai Trough. Isl. Arc, 17(3):342-357. doi:10.1111/ j.1440-1738.2008.00624.x

Jannasch, H.W., Wheat, C.G., Plant, J.N., Kastner, M., and Stakes, D.S., 2004. Continuous chemical monitoring with osmotically pumped water samplers: OsmoSampler design and applications. Limnol. Oceanogr.: Methods, 2(2):102-113. http://aslo.org/lomethods/free/2004/ 0102.pdf

Kimura, G., Screaton, E.J., Curewitz, D., and the Expedition 316 Scientists, 2008. NanTroSEIZE Stage 1A: NanTroSEIZE shallow megasplay and frontal thrusts. IODP Prel. Rept., 316. doi:10.2204/iodp.pr.316.2008

Kimura, G., Moore, G.F., Strasser, M., Screaton, E., Curewitz, D., Streiff, C., and Tobin, H., 2011. Spatial and temporal evolution of the megasplay fault in the Nankai Trough. Geochem., Geophys., Geosyst., 12:Q0A008Q0A030. doi:10.1029/2010GC003335

Kinoshita, M., Tobin, H., and Thu, M.K., 2007. NanTroSEIZE Stage 1: NanTroSEIZE LWD transect. IODP Sci. Prosp., 314. doi:10.2204/iodp.sp.314.2007

Kopf, A., Araki, E., Toczko, S., and the Expedition 332 Scientists, 2011. NanTroSEIZE Stage 2: riserless observatory. IODP Prel. Rept., 332. doi:10.2204/iodp.pr.332.2011

Moore, G.F., Bangs, N.L., Taira, A., Kuramoto, S., Pangborn, E., and Tobin, H.J., 2007. Three-dimensional splay fault geometry and implications for tsunami generation. Sci- 
ence, 318(5853):1128-1131. doi:10.1126/science. 1147195

Moore, G.F., Park, J.-O., Bangs, N.L., Gulick, S.P., Tobin, H.J., Nakamura, Y., Sato, S., Tsuji, T., Yoro, T., Tanaka, H., Uraki, S., Kido, Y., Sanada, Y., Kuramoto, S., and Taira, A., 2009. Structural and seismic stratigraphic framework of the NanTroSEIZE Stage 1 transect. In Kinoshita, M., Tobin, H., Ashi, J., Kimura, G., Lallemant, S., Screaton, E.J., Curewitz, D., Masago, H., Moe, K.T., and the Expedition 314/315/316 Scientists, Proc. IODP, 314/315/316: Washington, DC (Integrated Ocean Drilling Program Management International, Inc.). doi:10.2204/iodp.proc.314315316.102.2009

Moore, G.F., Taira, A., Klaus, A., Becker, L., Boeckel, B., Cragg, B.A., Dean, A., Fergusson, C.L., Henry, P., Hirano, S., Hisamitsu, T., Hunze, S., Kastner, M., Maltman, A.J., Morgan, J.K., Murakami, Y., Saffer, D.M., SánchezGómez, M., Screaton, E.J., Smith, D.C., Spivack, A.J., Steurer, J., Tobin, H.J., Ujiie, K., Underwood, M.B., and Wilson, M., 2001. New insights into deformation and fluid flow processes in the Nankai Trough accretionary prism: results of Ocean Drilling Program Leg 190. Geochem., Geophys., Geosyst., 2(10):1058-1079. doi:10.1029/2001GC000166

Moreno, M., Rosenau, M., and Oncken, O., 2010. 2010 Maule earthquake slip correlates with pre-seismic locking of Andean subduction zone. Nature (London, U. K.), 467(7312):198-202. doi:10.1038/nature09349

Obara, K., and Ito, Y., 2005. Accretionary prism earthquake along the Nankai Trough, southwest Japan. Eos, Trans. Am. Geophys. Union, 86(52)(Suppl.):T11E-06. (Abstract) http://www.agu.org/meetings/fm05/waisfm05.html

Orcutt, B., Wheat, C.G., and Edwards, K.J., 2010. Subseafloor ocean crust microbial observatories: development of FLOCS (flow-through osmo colonization system) and evaluation of borehole construction materials. Geomicrobiol. J., 27(2):143-157. doi:10.1080/01490450903456772

Saffer, D., McNeill, L., Araki, E., Byrne, T., Eguchi, N., Toczko, S., Takahashi, K., and the Expedition 319 Scientists, 2009. NanTroSEIZE Stage 2: NanTroSEIZE riser/riserless observatory. IODP Prel. Rept., 319. doi:10.2204/ iodp.pr.319.2009

Saffer, D., McNeill, L., Byrne, T., Araki, E., Toczko, S., Eguchi, N., Takahashi, K., and the Expedition 319 Scientists, 2010. Proc. IODP, 319: Tokyo (Integrated Ocean
Drilling Program management International, Inc.). doi:10.2204/iodp.proc.319.2010

Saito, S., Underwood, M.B., Kubo, Y., and the Expedition 322 Scientists, 2010. Proc. IODP, 322: Tokyo (Integrated Ocean Drilling Program Management International, Inc.). doi:10.2204/iodp.proc.322.2010

Screaton, E.J., Kimura, G., Curewitz, D., and the Expedition 316 Scientists, 2009. Expedition 316 summary. In Kinoshita, M., Tobin, H., Ashi, J., Kimura, G., Lallemant, S., Screaton, E.J., Curewitz, D., Masago, H., Moe, K.T., and the Expedition 314/315/316 Scientists, Proc. IODP, 314/315/316: Washington, DC (Integrated Ocean Drilling Program Management International, Inc.). doi:10.2204/iodp.proc.314315316.131.2009

Solomon, E.A., Kastner, M., Wheat, C.G., Jannasch, H., Robertson, G., Davis, E.E., and Morris, J.D., 2009. Longterm hydrogeochemical records in the oceanic basement and forearc prism at the Costa Rica subduction zone. Earth Planet. Sci. Lett., 282(1-4):240-251. doi:10.1016/j.epsl.2009.03.022

Strasser, M., Moore, G.F., Kimura, G., Kitamura, Y., Kopf, A.J., Lallemant, S., Park, J.-O., Screaton, E.J., Su, X., Underwood, M.B., and Zhao, X., 2009. Origin and evolution of a splay fault in the Nankai accretionary wedge. Nat. Geosci., 2(9):648-652. doi:10.1038/ngeo609

Taira, A., Hill, I., Firth, J.V., et al., 1991. Proc. ODP, Init. Repts., 131: College Station, TX (Ocean Drilling Program). doi:10.2973/odp.proc.ir.131.1991

Tobin, H.J., and Kinoshita, M., 2006. NanTroSEIZE: the IODP Nankai Trough Seismogenic Zone Experiment. Sci. Drill., 2:23-27. doi:10.2204/iodp.sd.2.06.2006

Tobin, H., Kinoshita, M., Moe, K.T., and the Expedition 314 Scientists, 2009. Expedition 314 summary. In Kinoshita, M., Tobin, H., Ashi, J., Kimura, G., Lallemant, S., Screaton, E.J., Curewitz, D., Masago, H., Moe, K.T., and the Expedition 314/315/316 Scientists, Proc. IODP, 314/315/316: Washington, DC (Integrated Ocean Drilling Program Management International, Inc.). doi:10.2204/iodp.proc.314315316.111.2009

Wessel, P., and Smith, W.H.F., 1991. Free software helps map and display data. Eos, Trans. Am. Geophys. Union, 72(41):441. doi:10.1029/90E000319

Publication: 11 December 2011 MS 332-105 
Figure F1. A. Seismic reflection line across NanTroSEIZE transect including drill holes of Stage 1 and 2 operations. AC $=$ accretionary prism. (Continued on next page.)

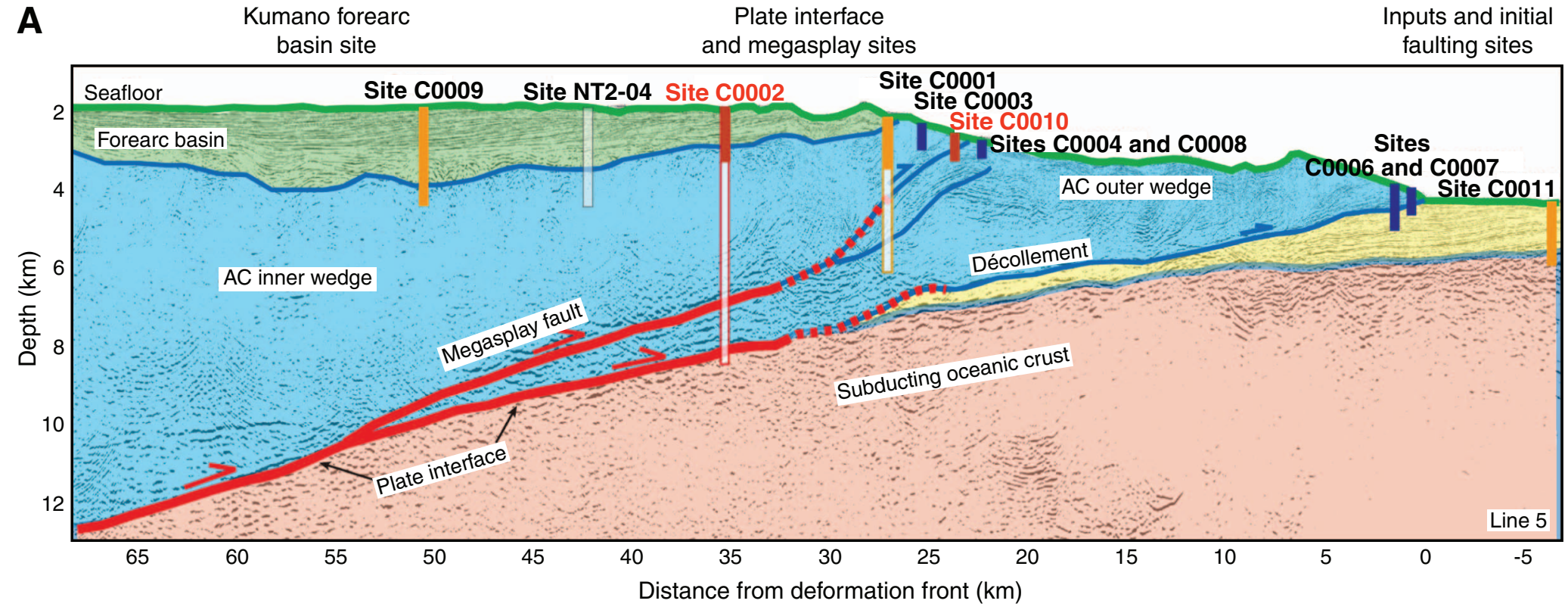


Figure F1 (continued). B. Shallow splay fault area at Site C0010 including schematic layout of casing with screens and position of long-term miniCORK assembly.

B

SmartPlug

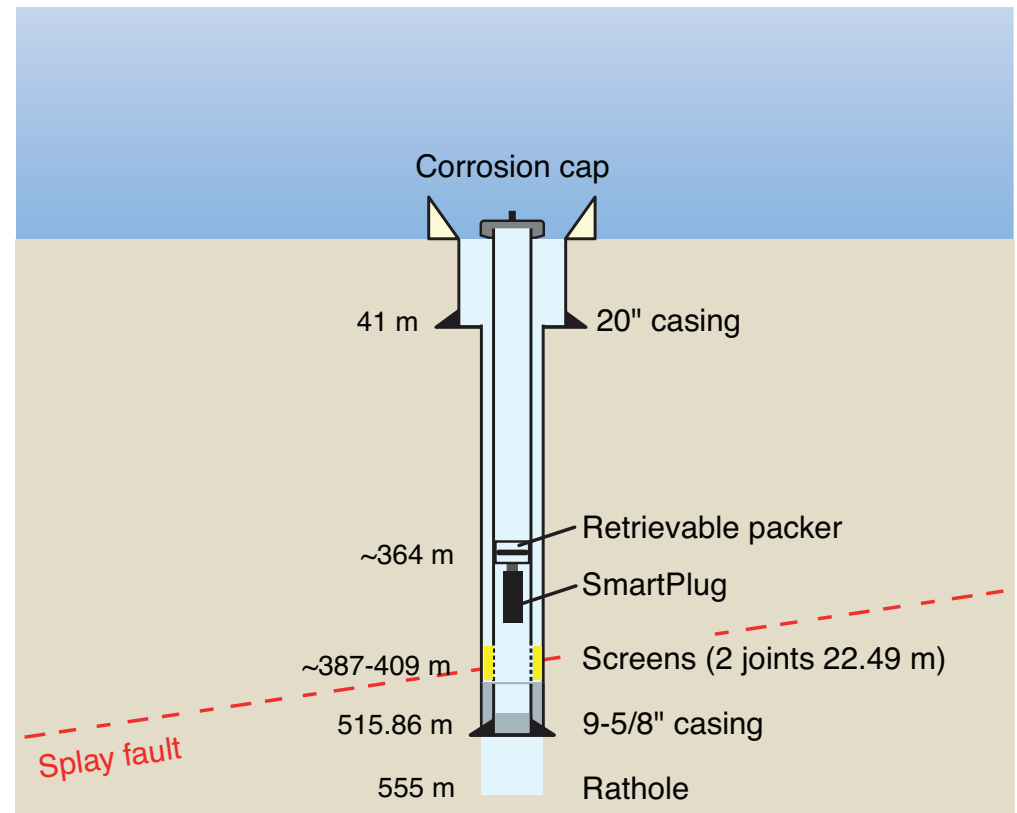

GeniusPlug

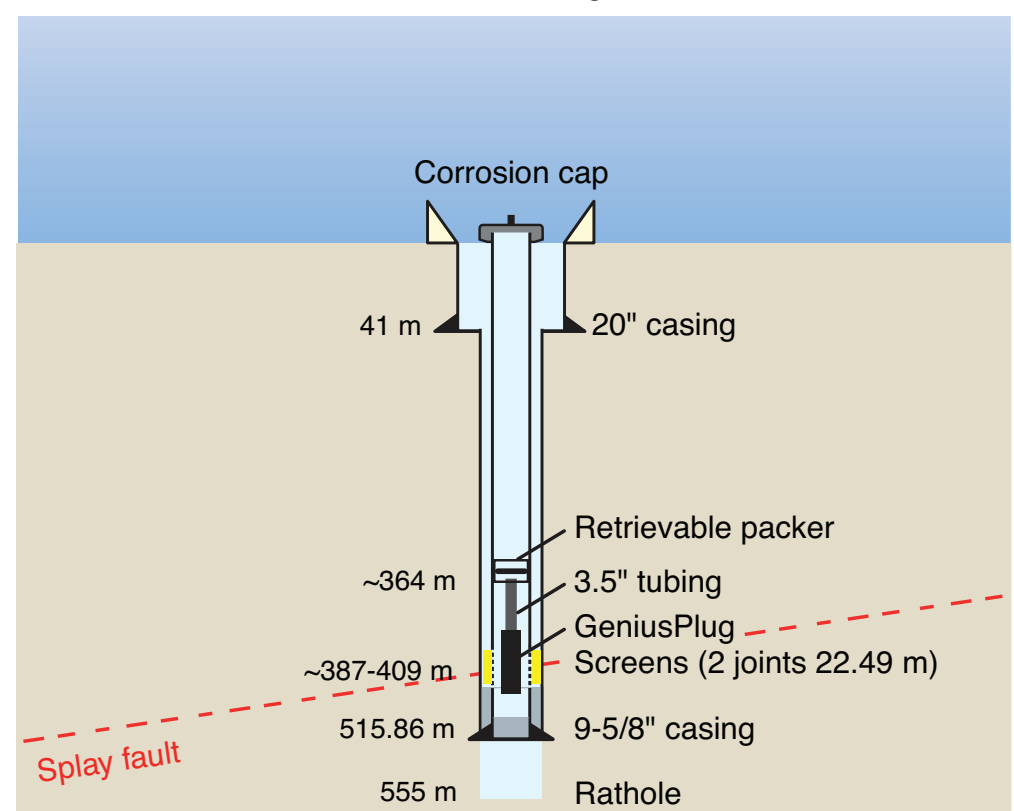


Figure F2. Schematic drawings of (A) SmartPlug unit and (B) GeniusPlug extension, Site C0010. MTL $=$ miniature temperature logger, PPC $=$ pressure period counter, FLOCS = flow-through osmo colonization system.

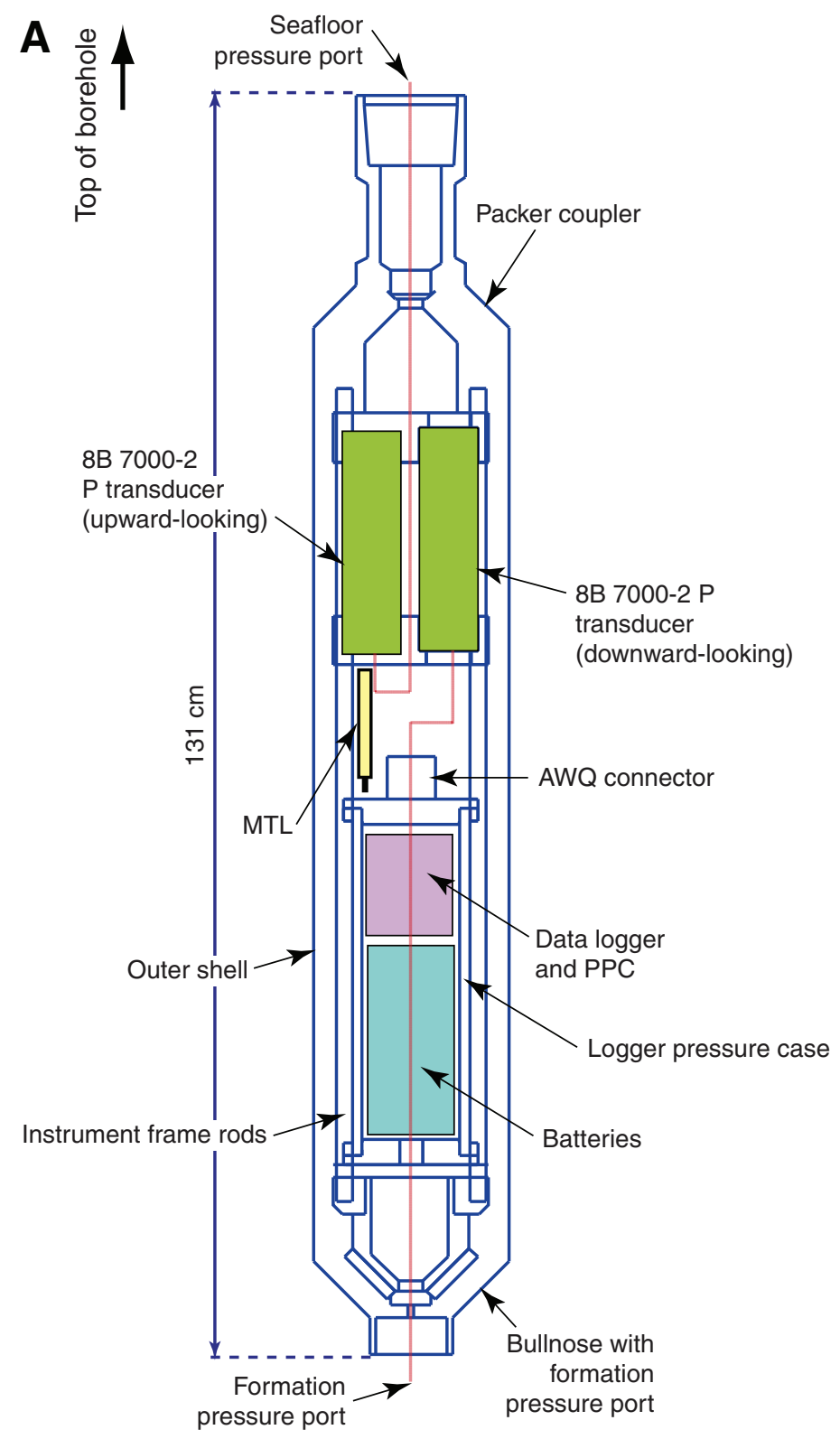

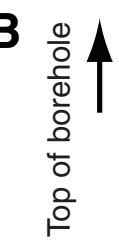

Connection to SmartPlug shell
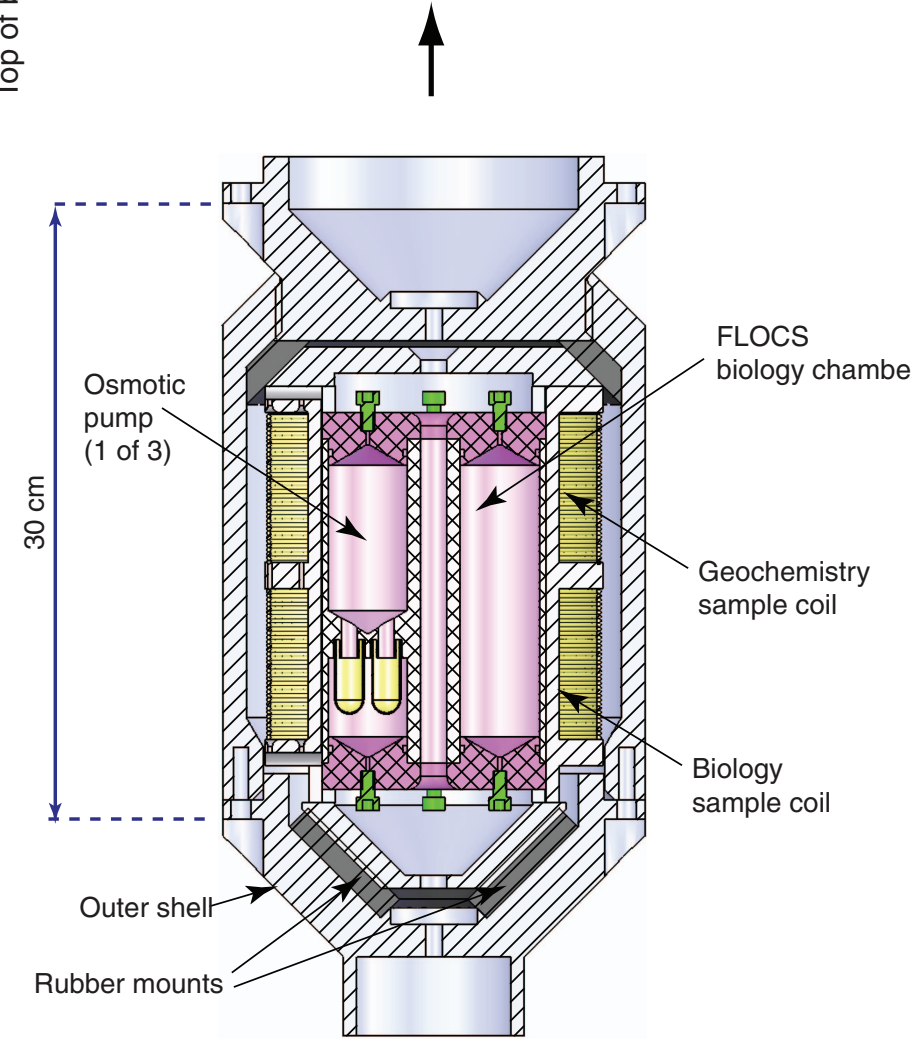
Figure F3. Photograph of SmartPlug instrument during final check prior to deployment, Site C0010. Note pressure transducers, miniature temperature logger $(\mathrm{MTL})$, and bottom tubing. RTC-PPC $=$ real-time clock pressure period counter.

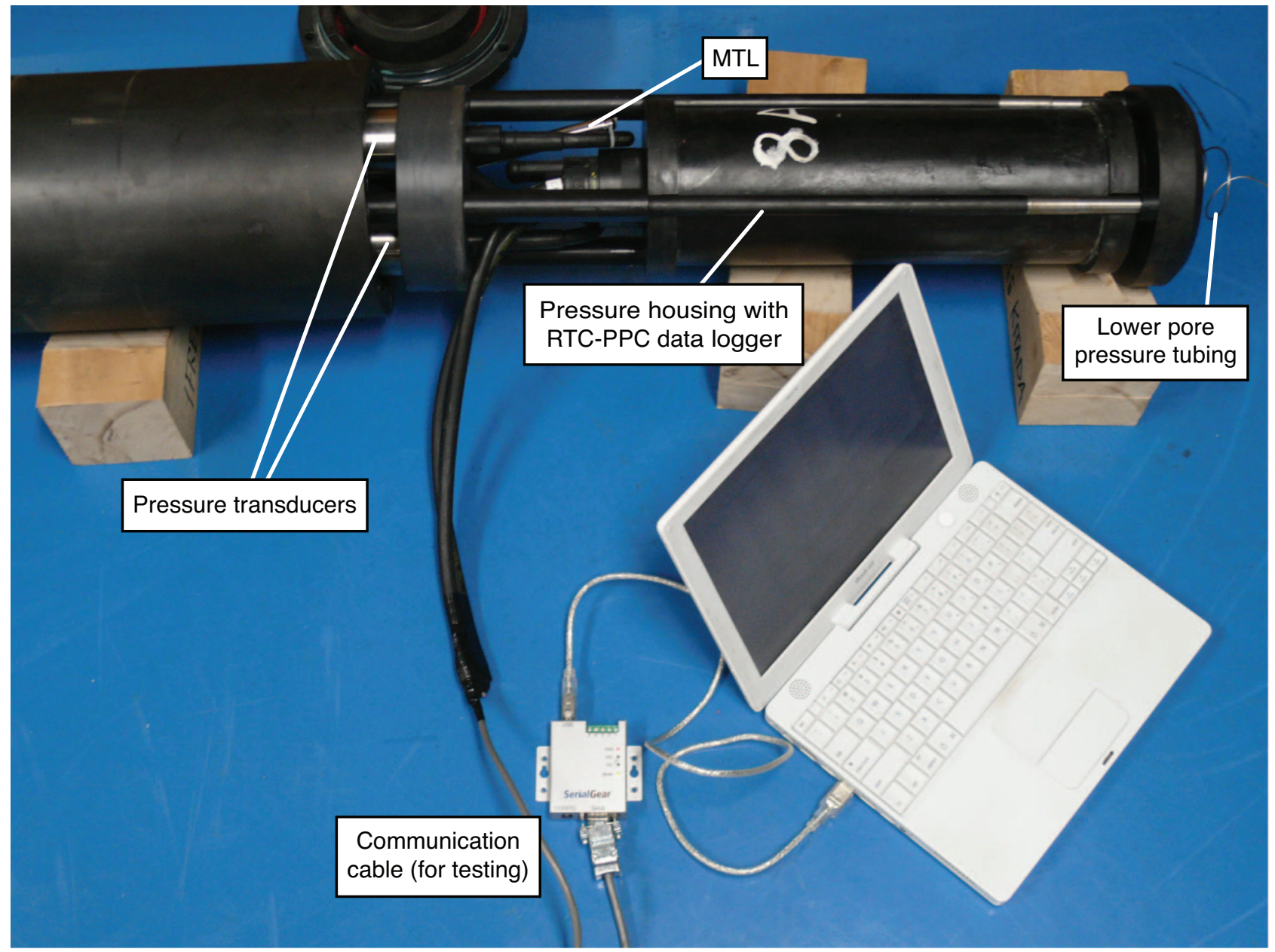


Figure F4. Photographs of (A) GeniusPlug extension unit containing OsmoSampler and flow-through osmo colonization system (FLOCS) cylinder and (B) OsmoSampler and FLOCS chambers after assembly in the Chikyu core laboratory, Site C0010.
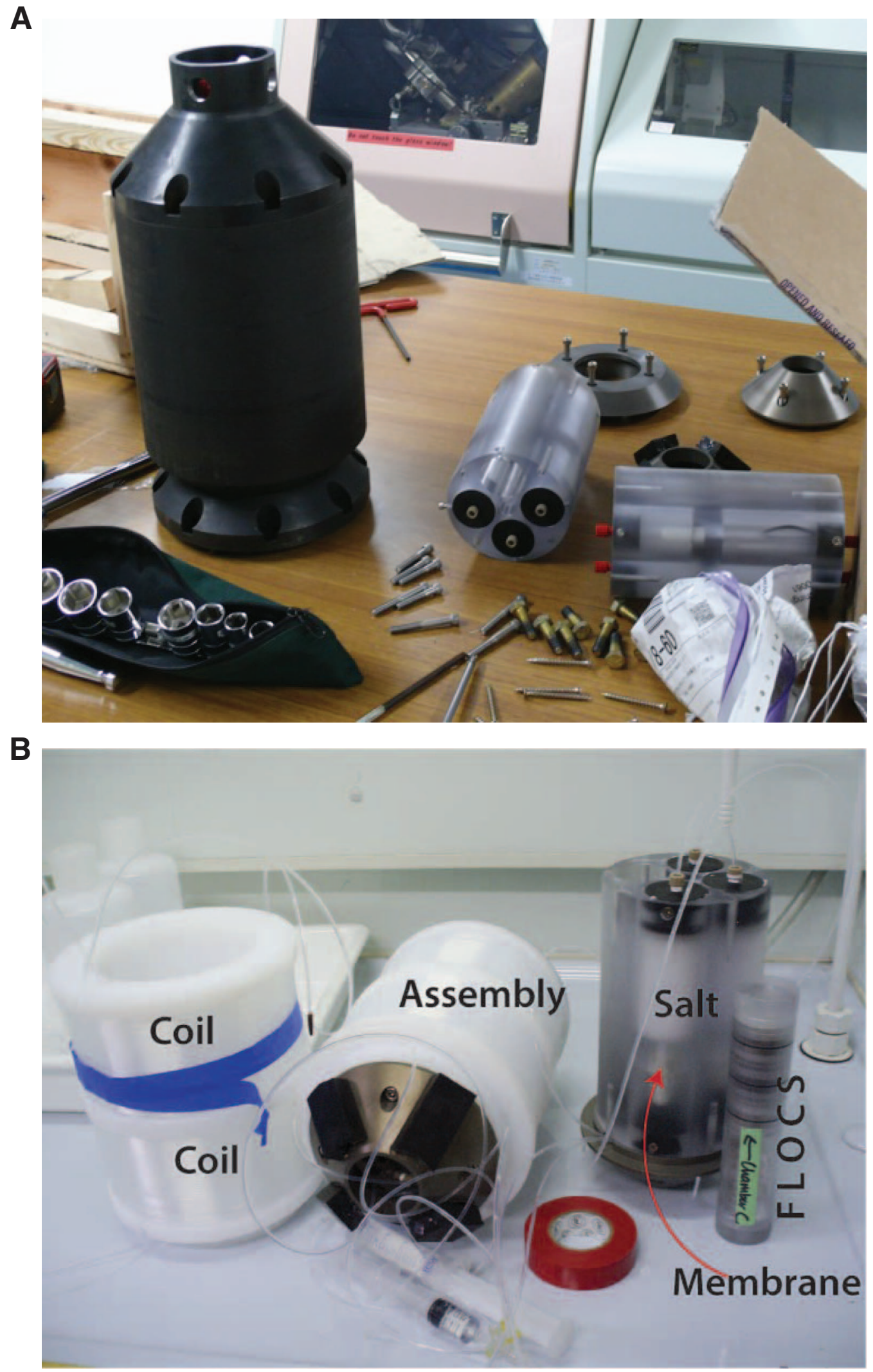


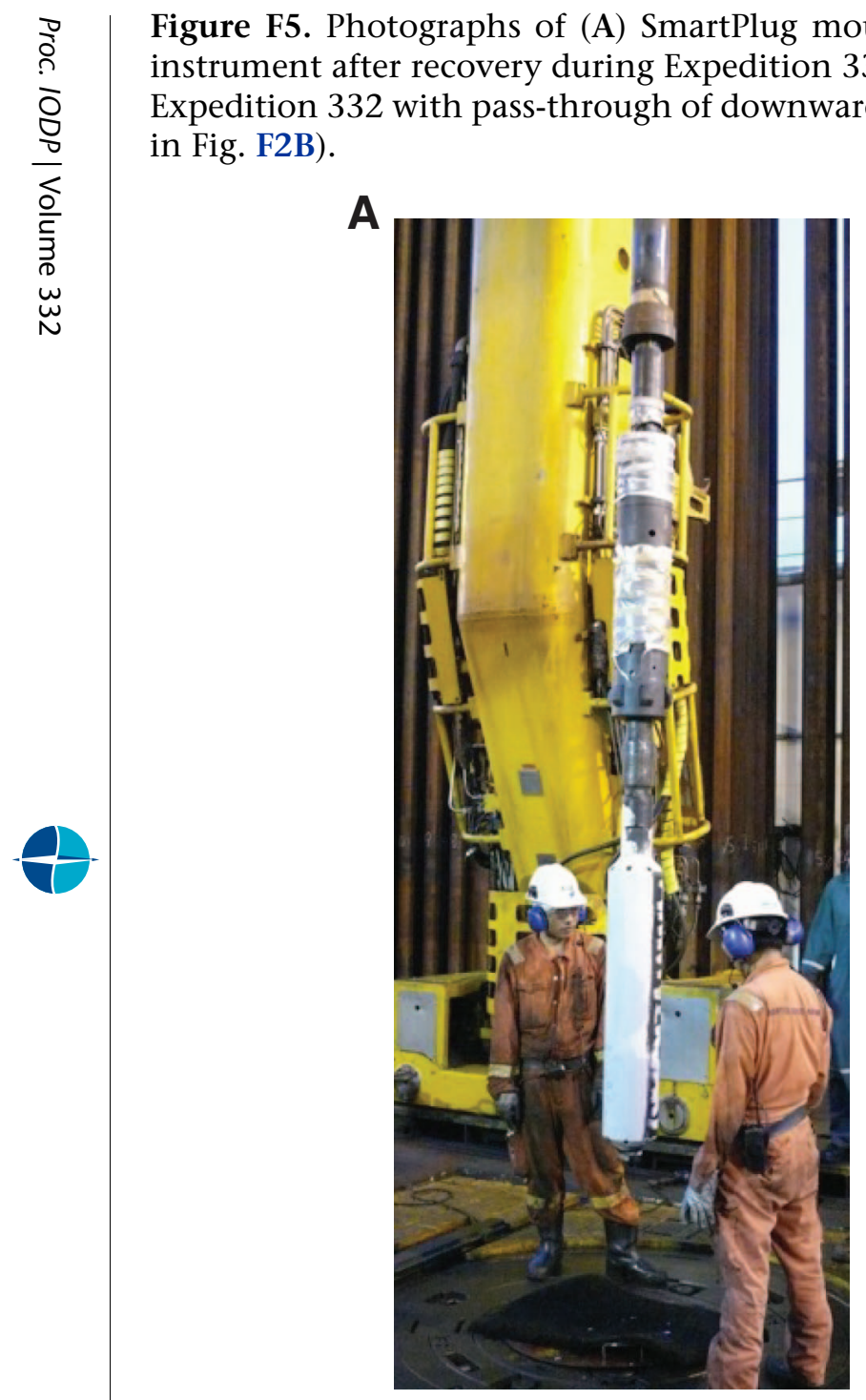

Figure F5. Photographs of (A) SmartPlug mounted to retrievable bridge plug prior to deployment during Expedition 319 and (B) SmartPlug

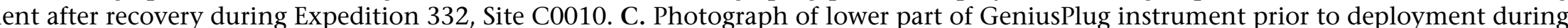
Expedition 332 with pass-through of downward-looking P transducer as well as intakes for OsmoSampler and FLOCS chamber (see also schematic

B

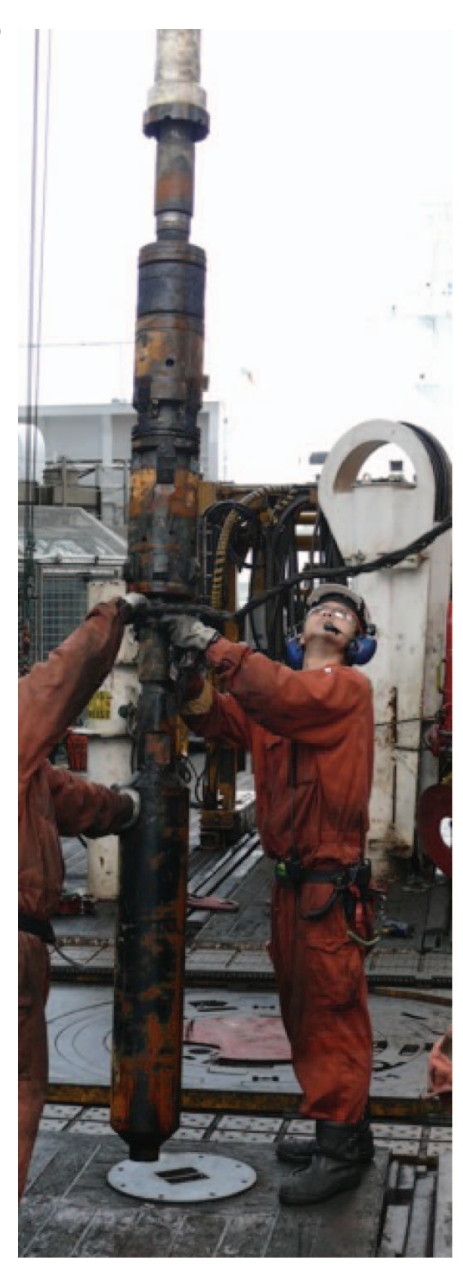

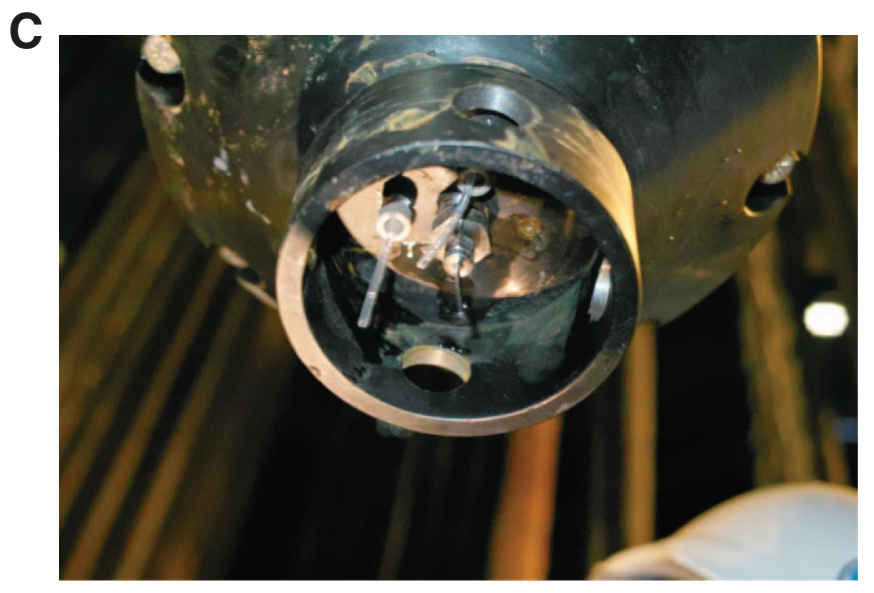


Figure F6. Still photographs by remotely operated vehicle (ROV) showing reentry with (A) SmartPlug during Expedition 319 and (B) GeniusPlug during Expedition 332, Site C0010.
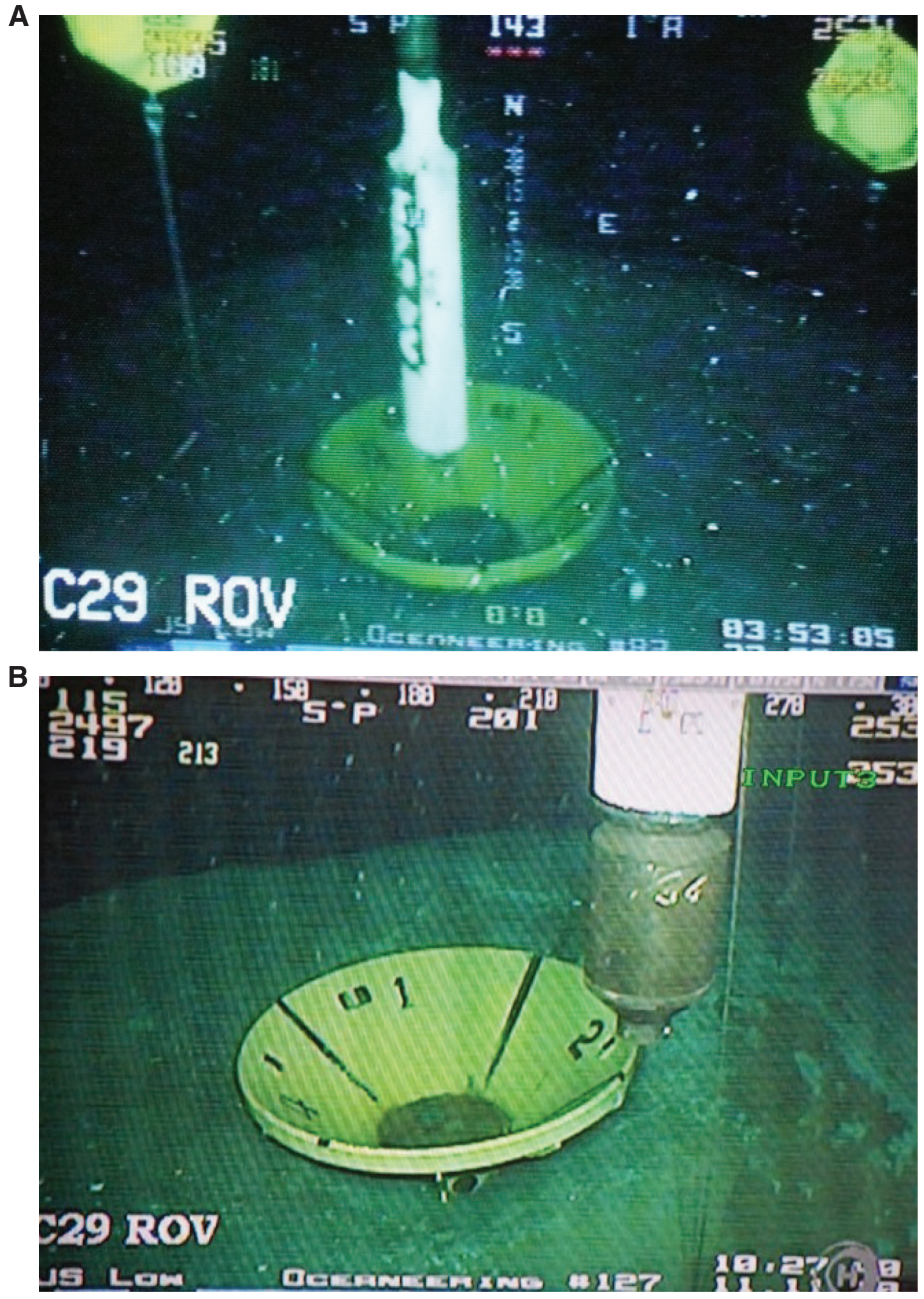
Figure F7. Overview of monitored (A) borehole pressure and (B) hydrostatic reference pore pressure as well as the resulting $(\mathbf{C})$ excess pore pressure. The pressure evolution can be separated in six periods of different transient change rates (see text for details).

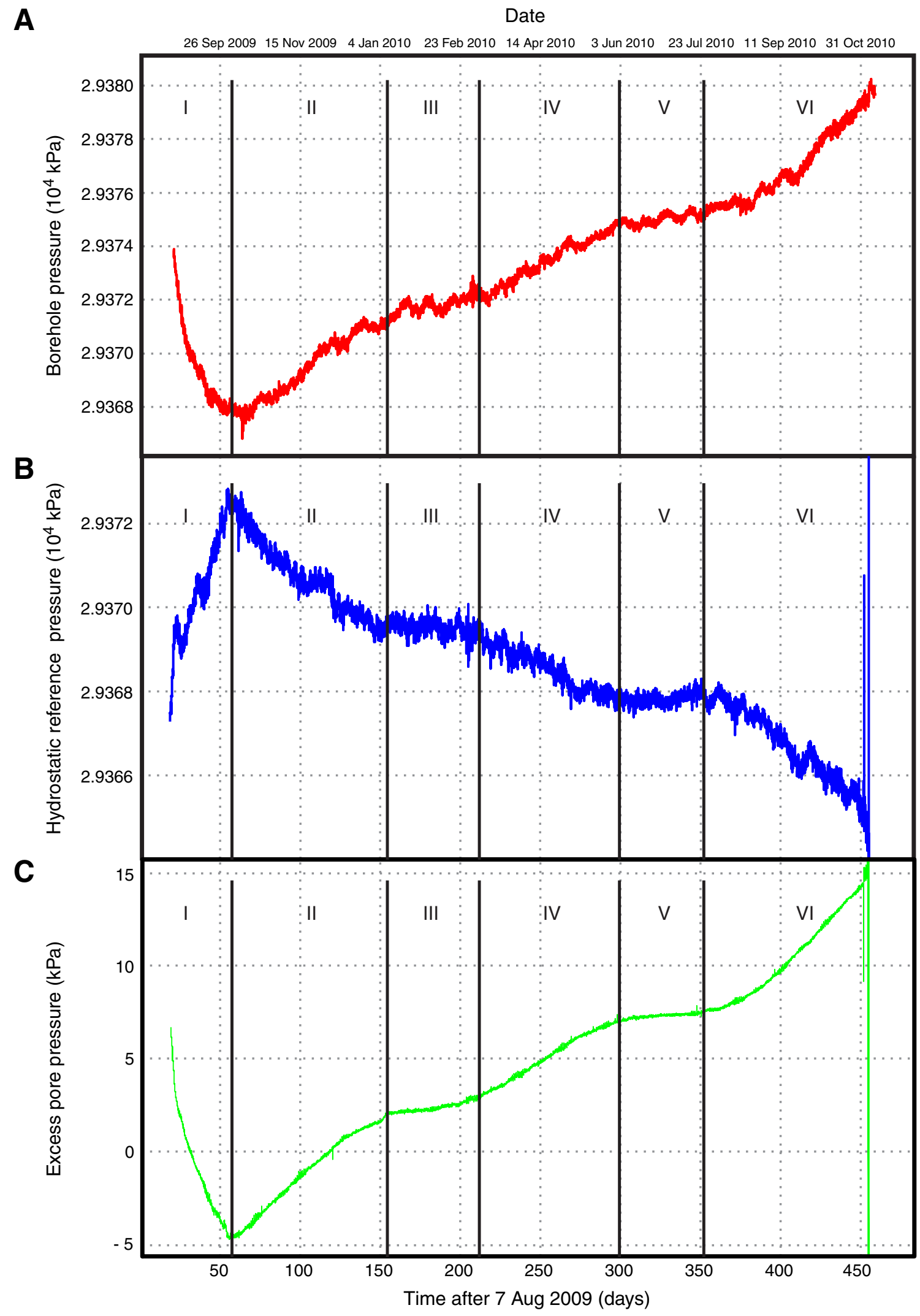



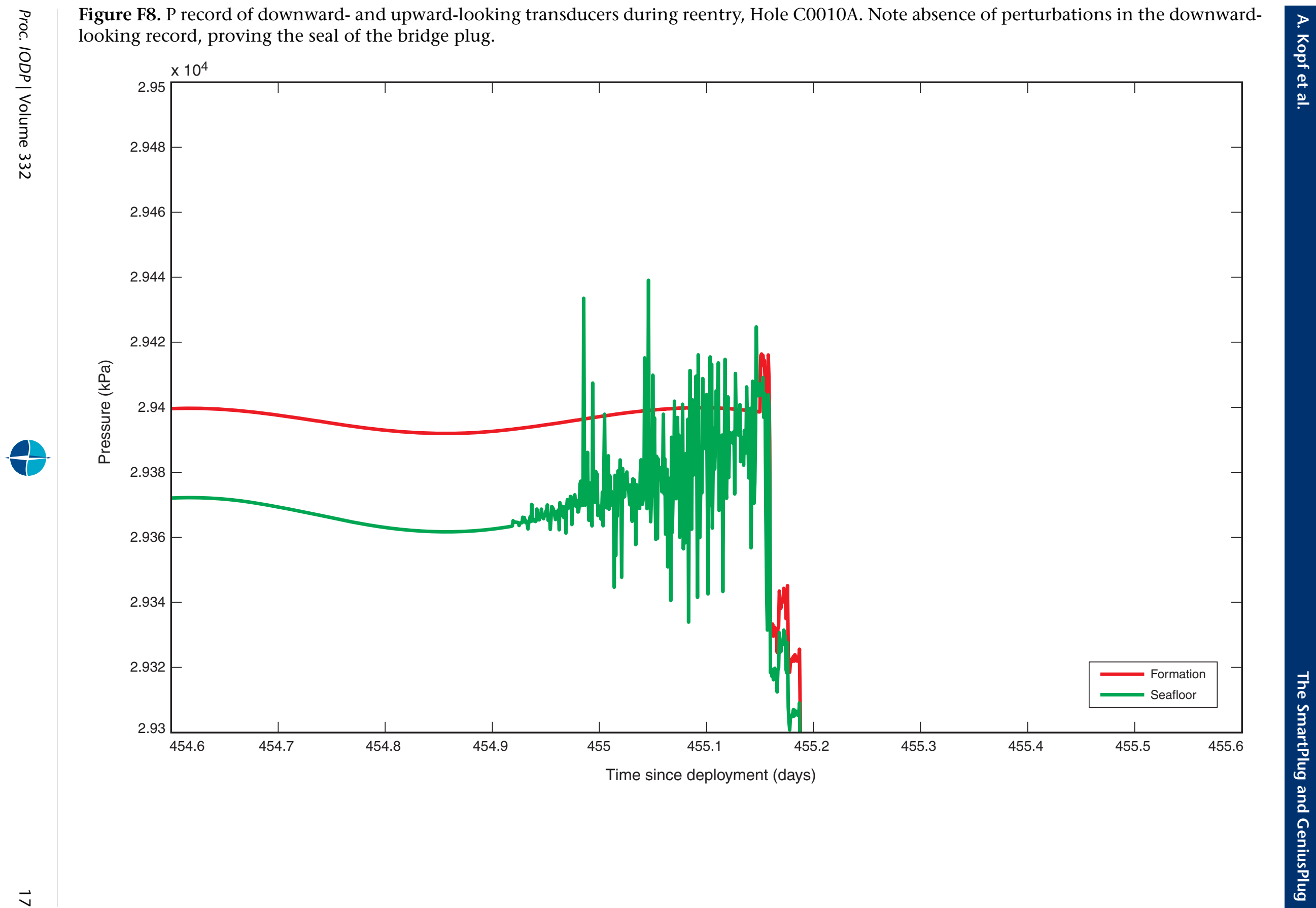
Figure F9. A. Map showing the epicenter and focal mechanism of the Chile M 8.8 earthquake on 27 February 2010. Focal mechanism was provided by www.globalcmt.org and map was generated using GMT (Wessel and Smith, 1991) and the ETOPO1 data set (Amante and Eakins, 2008). B. Pore pressure transients caused by the arrival of longitudinal seismic waves from Maule earthquake. C. Arrival of the tsunami wave caused by Maule earthquake, which is visible as tremorlike signal in the pore pressure data. The period of the amplitudes is up to $10 \mathrm{~min}$, as shown in the inset. Note that the tsunami arrived $\sim 23.5 \mathrm{~h}$ after the earthquake struck. UTC = Universal Time Coordinated.
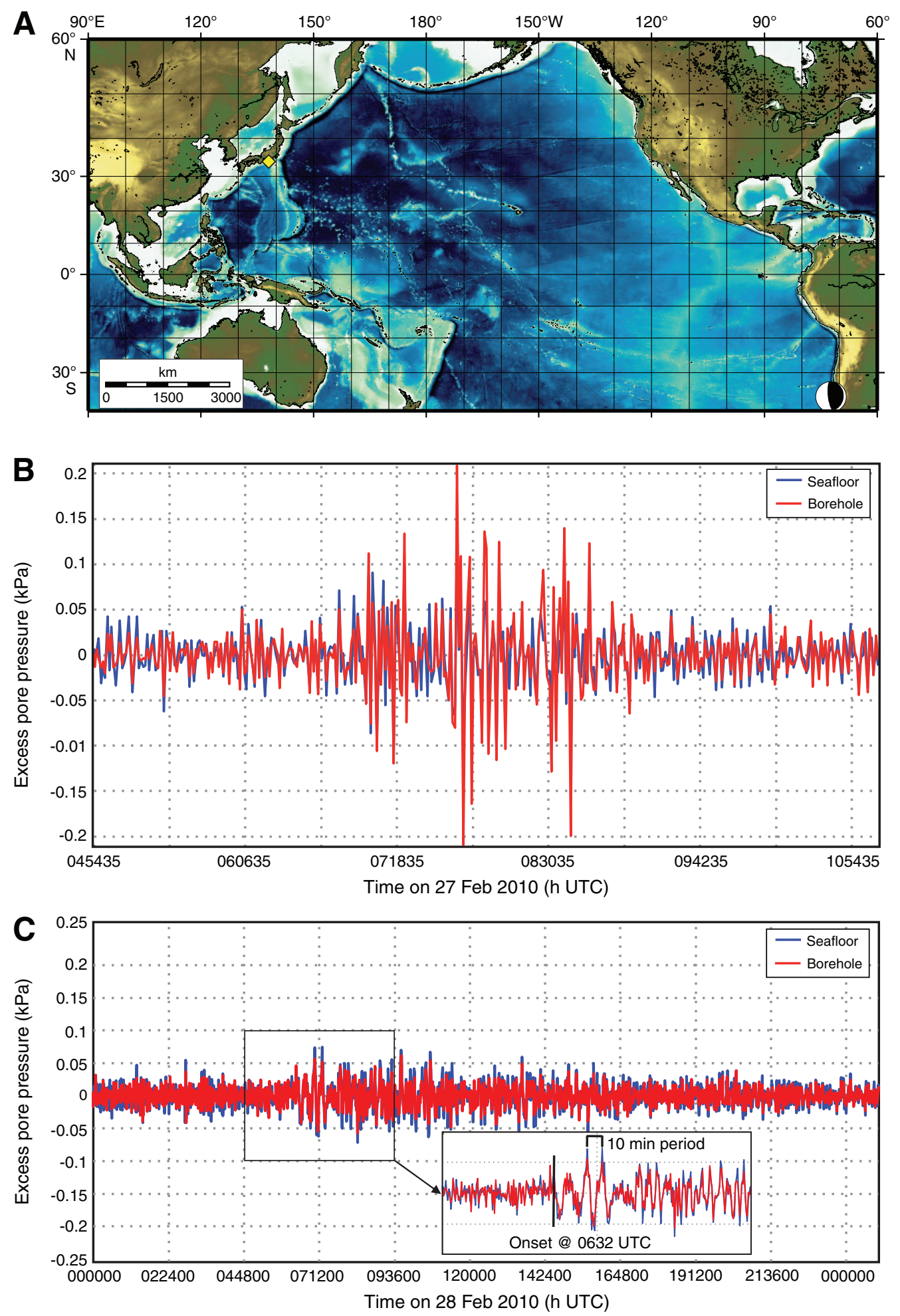
Figure F10. Examples of tremor- and steplike P transients caused by storms or very low frequency (VLF) earthquake swarms, respectively. A. Onset of microseism in the detided and high-pass filtered pore pressure data caused by the approach of Typhoon Chaba toward the end of the monitoring period (i.e., when the Chikyu was already at sea for Expedition 332). B. Excess pore pressure increase exceeding $300 \mathrm{~Pa}$, which is believed to have been caused by a swarm of VLF earthquakes within the Nankai Trough accretionary complex. See text.
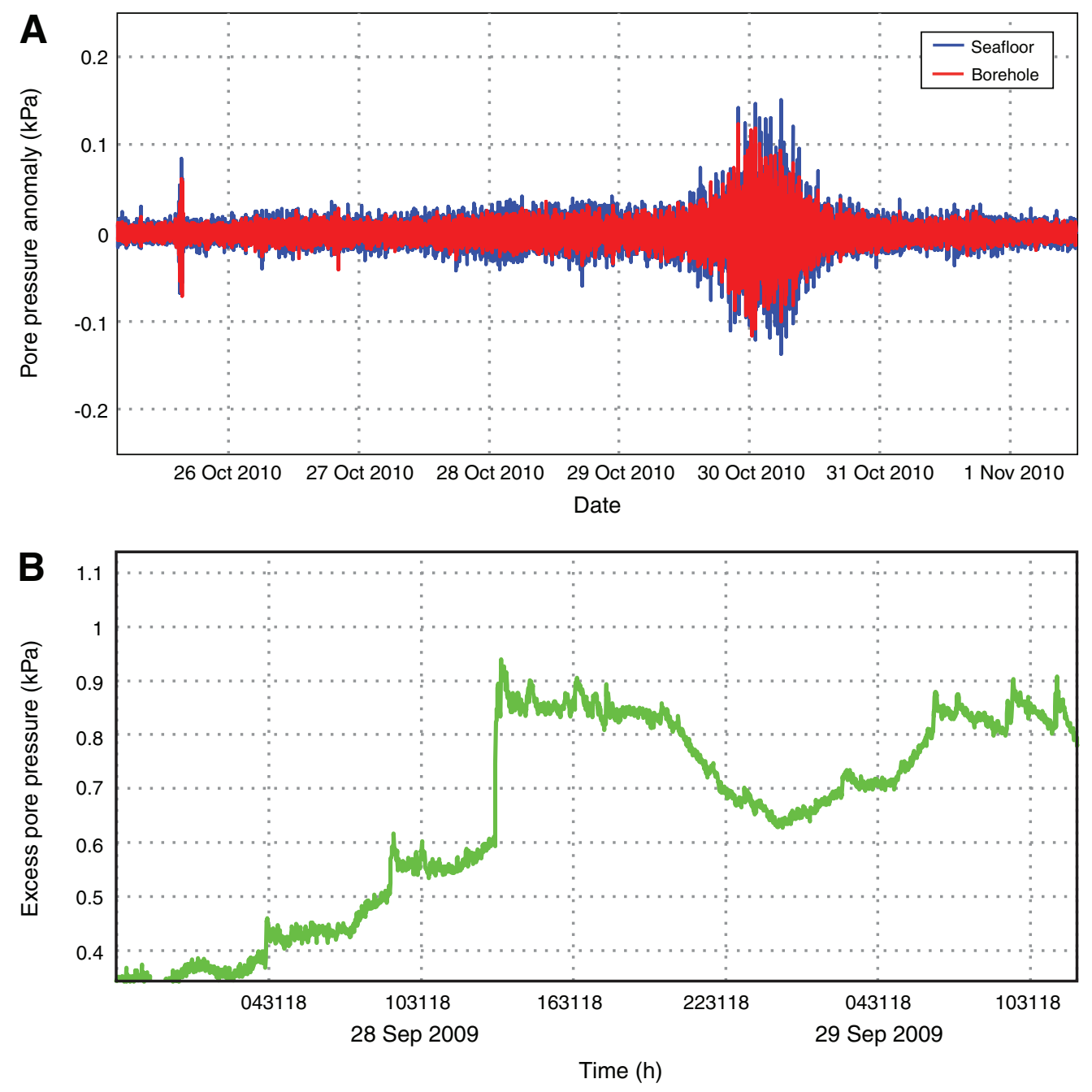
Figure F11. T record from platinum chip, MTL, and two P transducers. Main panel shows overview of temperature data obtained during the monitoring period, which was not sufficient to allow the temperature to reach in situ conditions. The strong variations and high amplitudes at the beginning and the end of the data are caused by deployment and recovery procedures, respectively. The data are otherwise free of any disturbance, except for the period highlighted in the inset. Here, it remains unclear what causes T to increase and decrease at the same point in time. Note that the P record does not show any anomaly at that time.

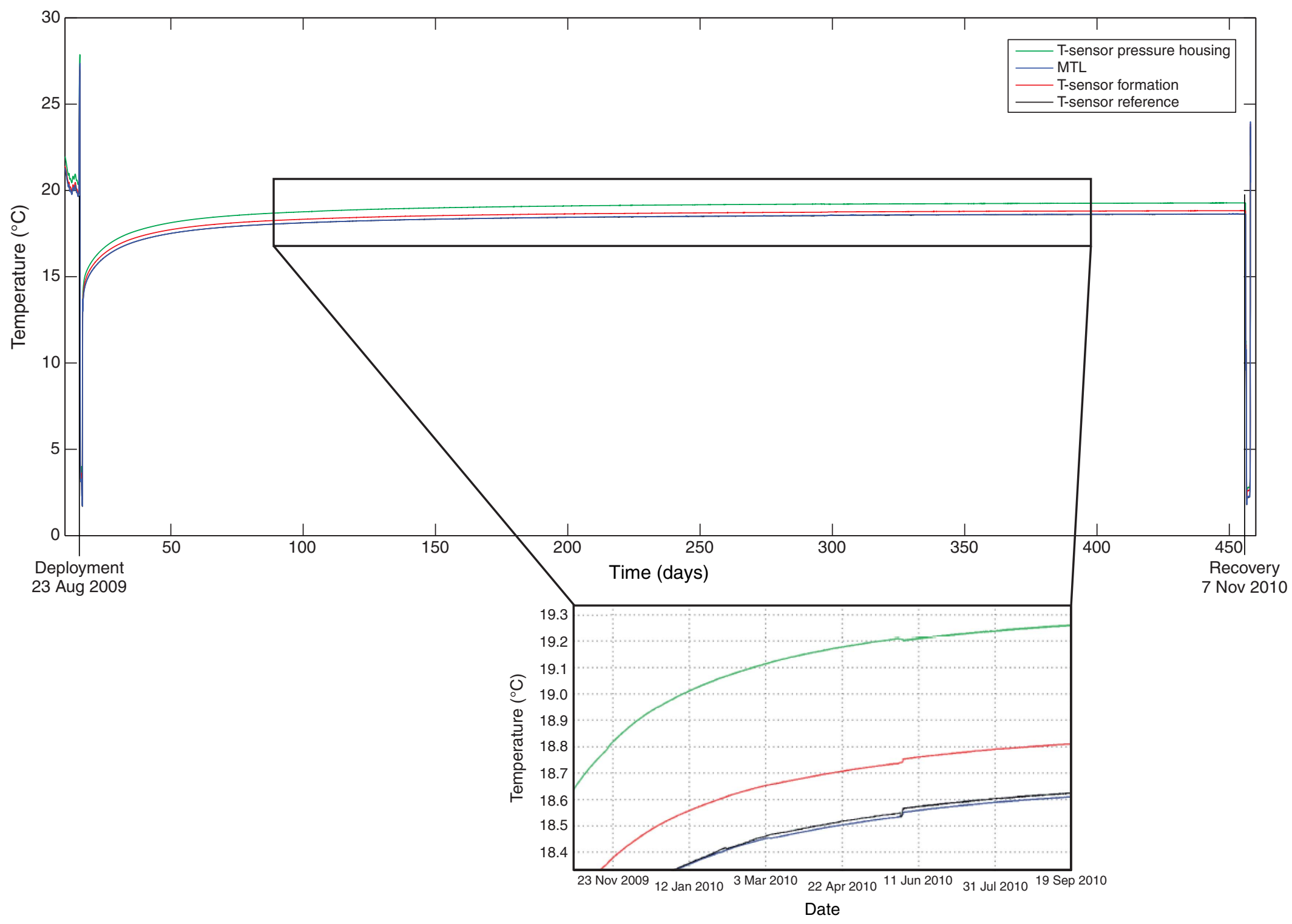

